\title{
A COMPARISON OF THE EFFECTIVENESS OF COGNITIVE BEHAVIOUR THERAPY AND ASSERTIVE TRAINING AGAINST THE ABILITY TO CONTROL VIOLENCE BEHAVIOUR IN SCHIZOPHRENIC PATIENTS
}

\author{
Sri Maryatun, ${ }^{1}$ Zullian Effendi, ${ }^{2}$ Sayang Ajeng Mardiyah ${ }^{3}$ \\ ${ }^{1,2}$ Nursing Science Study Program, Sriwijaya University, Street Palembang Prabumulih KM 32, \\ Indralaya District Ogan Ilir, South Sumatera 30662, Indonesia \\ ${ }^{3}$ Psychology Study Program, Sriwijaya University Street Palembang Prabumulih KM 32, \\ Indralaya District Ogan Ilir, South Sumatera 30662, Indonesia
}

\begin{abstract}
Violence behaviour is a maladaptive form of anger response that is dangerous and can hurt yourself, others and the environment. Therefore it is a concern for health workers to apply an effective and appropriate therapy to overcome these problems. This study was aimed to compare the differences in Cognitive Behavior Therapy (CBT) and Assertive Training (AT) in controlling violent behavior in schizophrenic patients.This study was used a quasi experimental pre-post test control group design.The number of samples was 30 respondents and taken by purposive sampling technique based on inclusion criteria. Samples of this study were schizophrenic patients with violent behavior totaling 30 people consisting of 10 people in the treatment group I who were given a standard of nursing care and CBT,10 people in the treatment group II who were given a standard of nursing care and AT and 10 people in the control group who only got the standard nursing behavior violent behavior.The results showed that there were differences in the patient's violent behavior between the treatment groups given $C B T, A T$ and the control group before and after the intervention was given with $C B T p=0.021$ and $A T p=0.032$. There was a significant difference between $C B T$ and AT in controlling violent behavior with a value of $p=0.015$. Based on the mean difference values, CBT have been better than AT in controlling violent behavior. CBT can improve patient's ability to control violent behavior. We recommend that CBT can be applied in health and community services
\end{abstract}

Keywords: Assertive training, cognitive behavior therapy, violent behavior

\begin{abstract}
ABSTRAK
Perilaku kekerasan adalah bentuk perilaku maladaptif dari respon kemarahan yang berbahaya dan dapat mencederai diri sendiri, orang lain dan lingkungan. Oleh karena itu menjadi perhatian bagi tenaga kesehatan menerapkan suatu terapi yang efektif dan tepat untuk mengatasi masalah tersebut. Penelitian ini bertujuan untuk membandingkan perbedaan Cognitive Behaviour Therapy (CBT) dan Assertive Training (AT) dalam mengendalikan perilaku kekerasan pada pasien skizofrenia.Metode penelitian ini menggunakan quasi ekperimental pre-post test control group design. Jumlah sampel sebanyak 30 responden dan diambil dengan teknik purposive sampling berdasarkan kriteria inklusi. Sampel penelitian ini adalah pasien skizoprenia dengan perilaku kekerasan berjumlah 30 orang terdiri dari 10 orang kelompok perlakuan I yang diberikan standar asuhan keperawatan dan CBT,10 orang kelompok perlakuan II yang diberikan standar asuhan keperawatan dan AT serta 10 orang kelompok kontrol yang hanya mendapatkan standar asuhan keperawatan perilaku kekerasan. Hasil penelitian menunjukkan ada perbedaan perilaku kekerasan pasien antara kelompok perlakuan yang diberikan CBT,AT dengan kelompok kontrol sebelum dan sesudah diberikan intervensi dengan hasil CBT $p=0,021$ dan ATp=0,032. Ada perbedaan yang signifikan antara CBT dengan AT dalam mengendalikan perilaku kekerasan dengan nilai $\mathrm{p}=0.015$. Berdasarkan nilai mean difference, intervensi CBT lebih baik daripada AT dalam mengendalikan perilaku kekerasan. CBT dapat meningkatkan kemampuan pasien dalam mengendalikan perilaku kekerasan. Diharapkan CBT dapat diterapkan di pelayanan kesehatan dan komunitas
\end{abstract}

Kata kunci : Assertive training, cognitive behaviour therapy, perilaku kekerasan

\footnotetext{
${ }^{1}$ Correspondece Address: Siti Maryatun, Nursing Science Study Program, Sriwijaya University, Street Palembang Prabumulih KM 32, Indralaya District Ogan Ilir, South Sumatera 30662, Indonesia, E-mail : tunce79@yahoo.com
} 


\section{Introduction}

Mental disorders with violent behavior is a condition which a person takes actions that can be physically dangerous for their self, and others, accompanied by uncontrolled emotions of anger. ${ }^{1}$ The lack of community knowledge about mental disorder and the stigma of mental illness which is considered to be a disgrace for the family, shameful and incurable, only makes the mental condition of the client getting worse and worse. ${ }^{2}$ The prevalence of mental disorders is more than 450 million people each year. ${ }^{3}$ Based on Rikesdas 2018 the prevalance shows that mental disorder gain $14,5 \%$ or 8 per mil households that means per 1,000 households there are 8 households with PMD (People with Mental Disorders). According to data from the medical record in Ernaldi Bahar Hospital in South Sumatra Province, the number of cases of violent behavior in 2018 amounted to 657 people with a recurrence rate of $9 \%$. Many patients with mental disorders (more than $80 \%$ ) will relapse and show progressive recurring episodes of the patient's functions including cognitive, social, work and psychosocial functions. ${ }^{4}$

This situation is requires serious attention and treatment from the government, the health department, the order of public health services in this case the hospital and public health center to prevent an increase in mental disorders in the coming year. For curative services, there is no single treatment that can improve many symptoms and disabilities in people with mental disorders. The Management of treatment of mental patients must be precise, comprehensive and ongoing care with the application of pharmacological, psycho-therapeutic, rehabilitative, psychosocial and family interventions and community support can reduce morbidity and mortality, improve patient treatment outcomes and improve quality of life. ${ }^{5}$ Cognitive Behavioral Therapy (CBT) becomes very effective in overcoming disruption of angry expressions and violent behavior because in this therapy group members learn strategies and techniques to help control anger, express anger in a healthy way, change hostility, and prevent aggression and violence. ${ }^{6}$ A similar study found that in the group that received Cognitive Behavioral Therapy there was a significant change in the decrease in symptoms or response to the violent behavior of schizophrenic patients in RSJD DR. RM Soedjarwadi Klaten from 77.86 to 49.79 with $p$ value $\leq \alpha 0.05{ }^{7}$

Besides Cognitive Behavioral Therapy, Assertive Therapy is one of the therapies to practice interpersonal communication skills in a variety of tense situations and emotional enhancement. ${ }^{8}$ This research was conducted by Rustafariningsih in 2018, it found that here was a decrease in cognitive responses that were cognitive, assertive, psychomotor in schizophrenic patients who had been given assertive training. ${ }^{9}$ This study was aimed to compare the differences in Cognitive Behavior Therapy (CBT) and Assertive Training (AT) in controlling violent behavior in schizophrenic patients 
positive changes in cognitive, attitude, psychomotor, and physiological responses in schizophrenic patients.

\section{Method}

This research is a quantitative study using the research design "Quasi Experimental Pre-Post Test With Control Group". Sampling technique using purposive sampling with inclusion criteria is male schizophrenia patients who were treated at Ernaldi Bahar Hospital in Palembang. He had a problems with violent behavior, willing to be a respondents, himself was not rampaging, have received medical therapy and nursing care according to standards. The independent variables in this study are Cognitive Behavioral Therapy (CBT) and Assertive Training (AT). The dependent variable in this study is violent behavior. The instrument of respondents violent behavior (dependent variable) used was a questionnaire and observation sheet developed by hastuti research including cognitive, affective, psychomotor and physiological responses. ${ }^{10}$

Data analysis processed with a statistical program includes univariate analysis in the form of frequency distributions. Univariate analysis produces frequency distribution tables and presentations of each variable as well as the mean, median and standard deviation. Equivalence analysis using Chi square, independent $t$ test. Bivariate analysis using paired t-test (dependent $t$ test) and one way ANOVA. This research had previously passed the ethical test and was declared feasible to conduct research with the issuance of an ethics letter from the faculty of medicine with Number 427 / KEPKRSMHFKUNSRI / 2019.

\section{Results}

Table 1 below show the results, education variable shows that the most respondents are at the elementary school level (36.6\%), while the majority of respondents are in single status $(53.3 \%)$. Respondents who have done frequency treated more than once were $(63.3 \%)$.

Table 1 was explained the results of the statistical analysis of the educational equality characteristics, marital status and frequency of care for patients at risk of violent behavior that was founded that there was no significant difference between the Cognitive Behaviour Therapy and the Assertive Trainining group because each characteristic had $\mathrm{p}$ value $\geq \alpha 0.05$. That means that both groups had the same or homogeneous variants. 
Table 1. Analysis of Educational Equality, Marital Status, Frequency of Hospitalization in Patients at Risk of Violent Behavior between the CBT \& the Assertive Training Group

\begin{tabular}{|c|c|c|c|c|c|c|c|c|c|}
\hline \multirow{2}{*}{ Characteristic } & \multicolumn{2}{|c|}{ CBT Group } & \multicolumn{2}{|c|}{ Assertive Group } & \multicolumn{2}{|c|}{ Control Group } & \multicolumn{2}{|c|}{ Total } & \multirow{2}{*}{ P value } \\
\hline & $\mathbf{n}$ & $\%$ & $\mathbf{N}$ & $\%$ & $\mathbf{n}$ & $\%$ & $\mathbf{n}$ & $\%$ & \\
\hline \multicolumn{10}{|l|}{ Education } \\
\hline Elementary & 5 & 16.6 & 4 & 13.3 & 2 & 6.6 & 11 & 36.6 & \multirow{4}{*}{0.606} \\
\hline Junior High School & 2 & 6.6 & 3 & 0.1 & 2 & 6.6 & 7 & 23.3 & \\
\hline Senior high school & 2 & 6.6 & 2 & 6.6 & 4 & 13.3 & 8 & 26.6 & \\
\hline College & 1 & 3.3 & 1 & 3.3 & 2 & 6.6 & 4 & 13.3 & \\
\hline \multicolumn{10}{|l|}{ Marriage Status } \\
\hline Married & 2 & 6.6 & 3 & 0.1 & 4 & 13.3 & 9 & 0.3 & \multirow{3}{*}{0.558} \\
\hline Single & 6 & 0.2 & 5 & 16.6 & 5 & 16.6 & 16 & 53.3 & \\
\hline Divorced & 2 & 6.6 & 2 & 6.6 & 1 & 3.3 & 5 & 16.6 & \\
\hline \multicolumn{10}{|l|}{ Frequency treated } \\
\hline First & 4 & 13.3 & 3 & 0.1 & 4 & 13.3 & 11 & 36.6 & \multirow{2}{*}{0.473} \\
\hline More & 6 & 0.2 & 7 & 23.3 & 6 & 0.2 & 19 & 63.3 & \\
\hline
\end{tabular}

Based on table 2 below, it was found that there were no significant differences in the average age of respondents and length of stay in the group given CBT intervention and Assertive Training which showed that both groups had the same or homogeneous variance with $p$ value $a>0.05$.

Table 2. Analysis of Age and Length of Care for the CBT Intervention Group and Assertive Training in Patients at Risk of Violent Behavior

\begin{tabular}{lccccc}
\hline \multicolumn{1}{c}{ Variables } & Groups & n & Mean & SD & p value \\
\hline \multirow{3}{*}{ Age } & CBT & 10 & 35.21 & 9.034 & \\
& Assertive training & 10 & 34.06 & 10.065 & 0.327 \\
\multirow{2}{*}{ Duration of treated } & Control & 10 & 31.27 & 9.071 & \\
& CBT & 10 & 3.10 & 1.262 & \\
& Assertive training & 10 & 2.98 & 1.455 & 0.229 \\
& control & 10 & 2.97 & 1.322 & \\
\hline
\end{tabular}

Based on the table 3 below, it was found that aspects of violent behavior in patients consisting of cognitive, affective, psychomotor and physiological responses had similar or homogeneous similarities in the three groups before getting CBT intervention, Assertive Training and control groups with statistical test results ( $\mathrm{p}$ value $>\mathrm{a} 0,05$ ) 
Table 3. Equality Analysis Ability to Manage Anger in the Group of Patients with Violent Behavior Given Cognitive Behavior Therapy (CBT) Assertive Training and the Control Group

\begin{tabular}{lllllcc}
\hline Aspects & \multicolumn{1}{c}{ Groups } & n & Mean & SD & Min-max & p value \\
\hline \multirow{3}{*}{ Cognitive } & CBT & 10 & 20.22 & 3.103 & Dec-24 & \\
& Assertive & 10 & 21.38 & 3.021 & Oct-22 & 0.196 \\
& Control & 10 & 23,11 & 3.245 & $13-24$ & \\
Affective & CBT & 10 & 19.08 & 3.201 & Aug-22 & \\
& Assertive & 10 & 19.06 & 2.668 & $11-20$ & 0,703 \\
& Control & 10 & 21.02 & 3.445 & $12-23$ & \\
Psychomotor & CBT & 10 & 17.74 & 2,446 & Sep-23 & \\
& Assertive & 10 & 17.69 & 2.407 & Sep-22 & 0,153 \\
& Control & 10 & 19.67 & 3.213 & $11-23$ & \\
Physiological & CBT & 10 & 09.65 & 1.074 & $07-$ Oct & \\
& Assertive & 10 & 08.44 & 1.098 & $07-$ Nov & 0,573 \\
& Control & 10 & 10.11 & 1.987 & $09-$ Dec & \\
Violent Behavior & CBT & 10 & 66.69 & 7.769 & $58-88$ & \\
& Assertive & 10 & 63.57 & 7.064 & $56-77$ & 0,775 \\
& Control & 10 & 69.91 & 97.69 & $57-90$ & \\
\hline
\end{tabular}

Analysis of the results of table 4 below, the patient's ability in terms of cognitive aspects has increased significantly with $\mathrm{p}$ value of $0,000(a<0.05)$. Similarly, the affective response of violent behavior decreased by 09.00 and $\mathrm{p}$ value 0.001 which means that there was a statistically significant change. The ability to control violent behavior viewed from psychomotor aspects also increased significantly marked by p value $0.001(a<0.05)$ with the average value decreasing by 06.46 from 17.74 to 11.28 . A decrease in physiological response also occurred in patients by 03.44 with $p$ value $=0,000$ which means that there was a change in statistics after the patient was given CBT intervention. For all components of violent behavior, there was a decrease in the response of violent behavior by 25,98 with ( $\mathrm{p}$ value 0,000 ) indicating that there was statistically significant changes between before and after CBT intervention was given.

Table 4. Ability to Control Violent Behavior Before and After Intervention Cognitive Behavior Therapy (CBT)

\begin{tabular}{lllccc}
\hline \multicolumn{1}{c}{ Ability } & \multicolumn{1}{c}{ Pre/ post } & Mean & $\begin{array}{c}\text { SD } \\
\text { Deviation }\end{array}$ & T & p value \\
\hline \multirow{3}{*}{ Cognitive } & Before & 20.22 & & & \\
& After & 13.14 & 3.103 & 1.666 & 0.000 \\
& Deviation & 07.08 & & & \\
Affective & Before & 19.08 & & & \\
& After & 10.08 & 3.201 & 1.673 & 0.001 \\
& Deviation & 09.00 & & & \\
Psychomotor & Before & 17.74 & & & \\
& After & 11.28 & 2.446 & 0.897 & 0.001 \\
& Deviation & 06.46 & & & \\
Physiologicals & Before & 09.65 & & & \\
& After & 06.21 & 1.074 & 0.306 & 0.000 \\
& Deviation & 03.44 & & & \\
Violent Behavior & Before & 66.69 & & & \\
& After & 40.71 & 7.769 & 1.027 & 0.000 \\
& Deviation & 25.98 & & & \\
\hline
\end{tabular}


Patients were able to control violent behavior after being given Assertive Training based on the results of table 5 below, where cognitive aspects decreased by 06.35 from 21.38 to 15.03 and significant changes were marked by p value $0.019(a<0.05)$. Similar results were obtained from affective responses which also decreased by 10.39 with a $\mathrm{p}$ value of $0,000(\mathrm{a}<0.05)$, psychomotor responses, physiological responses which means that there was a statistically significant change. For all components of violent behavior, there was a decrease in the response of violent behavior by 20.92 with ( $\mathrm{p}$ value 0.001 ) indicating that there was a statistically significant change between after and before the Assertive Training intervention was given.

Table 5. Ability to Control Violent Behavior Before and After Assertive Training Intervention

\begin{tabular}{lllccc}
\hline \multicolumn{1}{c}{ Ability } & \multicolumn{1}{c}{ Pre/ post } & Mean & $\begin{array}{c}\text { SD } \\
\text { Deviation }\end{array}$ & T & p value \\
\hline \multirow{3}{*}{ Cognitive } & Before & 21.38 & & & \\
& After & 15.03 & 3.021 & -1.694 & 0.019 \\
& Deviation & 06.35 & & & \\
Affective & Before & 19,06 & & & \\
& After & 08.97 & 2.688 & 0.667 & 0.000 \\
& Deviation & 10,09 & & & \\
Psychomotor & Before & 17.69 & & & \\
& After & 12.88 & 2.427 & -1.223 & 0.000 \\
& Deviation & 04.81 & & & \\
Physiological & Before & 08.44 & & & \\
& After & 05.77 & 1.098 & 0.337 & 0.001 \\
& Deviation & 02.67 & & & \\
Violent Behavior & Before & 63.57 & & & \\
& After & 42.65 & 7.043 & -1.463 & 0.001 \\
& Deviation & 20.92 & & & \\
\hline
\end{tabular}

Table 6 below shows that there were delta differences between the treatment groups (CBT and Assertive training) and the control group with $p$ value $0,017(a<0.05)$. This means that there was significant differences between the intervention group CBT, AT and the control group to control the violent behavior of schizophrenic patients.

Table 6. Differences in The Effects of Cognitive Behavior Therapy(CBT) Compared with Assertive Training (AT) and Control Groups on Abilities Controlling Violent Behavior

\begin{tabular}{cccc}
\hline Intervention & Mean & $\begin{array}{c}\text { Deviation } \\
\text { Standard }\end{array}$ & p value \\
\hline CBT & $-5,23$ & 0,672 & \\
AT & $-2,75$ & 0,325 & 0,017 \\
Control & $-1,02$ & 0,192 & \\
\hline
\end{tabular}

In table 7, it was found that the $\mathrm{CBT}$ and $\mathrm{AT}$ interventions given to the intervention group had a better influence in controlling violent behavior compared to the control group. Anova Test difference between the intervention group and the control group (CBT and AT) was showed the 
value of delta $p$ value in each intervention of the treatment group is as follows CBT $p=0.021$, AT $\mathrm{p}=0.032$. Based on the delta $\mathrm{p}$ value in table 7 , it can be concluded that the most influential on the ability to control the violent behavior of schizophrenic patients was Cognitive Behavior Therapy (CBT) and then Assertive Training (AT).

Table 7. The Effect of The Intervention Group Treatment (CBT, AT) Compared to The Control Group (SP) on The Ability to Control Violent Behavior in Schizophrenic Patients

\begin{tabular}{|c|c|c|c|c|c|c|}
\hline \multirow{2}{*}{ Variabel } & \multicolumn{5}{|c|}{ Average Difference Mean } & \multirow{2}{*}{$P$ value } \\
\hline & Cognitive & Affective & Psychomotor & Physiological & Composit & \\
\hline Control and CBT & 5.73 & 8.91 & 4.86 & 3.27 & 24.06 & 0.021 \\
\hline Control and AT & 5.00 & 10.3 & 3.21 & 2.5 & 19.00 & 0.032 \\
\hline CBT and AT & 0.73 & -1.39 & 1.65 & 0.77 & 5,06 & 0.015 \\
\hline
\end{tabular}

\section{Discussion}

The last level of education taken by someone is a vehicle to underlie someone behaving scientifically. A low level of education will be difficult to digest the message or information conveyed. ${ }^{11}$ According on the first table most respondents with a high school or secondary education background. However, the high level of education does not guarantee a person can behave properly. Intellectual education must be balanced with character education so that someone can solve problems with wisdom. ${ }^{12}$

Age affects a person's thinking maturity. The more he gets older, the more mature he is in thinking .In this study, respondents had an average age of 35 years both in the Cognitive Behavioral Therapy (CBT), Assertive Training (AT) and control groups. However, increasing age does not necessarily make a person become more mature in attitude and behavior. It is the experience and process of living life are factor that a person can become more responsible, able to resolve problems and conflicts adaptive. ${ }^{13}$

The task of human development at the stage of growth and development of middle and upper adulthood is marriage. ${ }^{14}$ Stuart stated that individuals who experience divorce or do not have a partner, had including high risk groups experiencing psychological problems. ${ }^{15}$ In this study, most respondents were not married with an average age of 35 years and they were taken by their families to be treated at the Erba Mental Hospital because of problems of violent behavior caused by low self-esteem. Someone who is old in age but he is not married, then he will experience low selfesteem $^{16}$.

Based on table 1, the average respondent had experienced the frequency of being treated at Erba Mental Hospital more than once. The frequency of patient recurrence was high when caregiver support was decreased. ${ }^{17}$ The length of stay is the time or duration of exposure to a 
stressor that is related to when, how long and how much frequency, will have an impact on whether or not someone is able to practice the ability acquired. ${ }^{1}$ Picked up by his family even though sometimes they have not been able to overcome their own problems. Individual characteristics that can affect stress are the level of personal control, the availability of social support, feelings of ability and cognitive appreciation.

The ability of clients in controlling violent behavior increases significantly as shown in table 4, where all violent behavioral responses, namely cognitive, affective, psychomotor and physiological aspects, $\mathrm{p}$ value $<0.05$. While after getting Cognitive Behavioral Therapy (CBT) where as before intervention the average ability of the client is at a low level. These results are in line with Ketut's research, 2013 where $77 \%$ of clients were able to reduce the response to violent behavior and were at an intermediate level of ability. Cognitive Behavioral Therapy (CBT) aims to change irrational beliefs, reasoning errors and negative statements about the existence of individuals.

Bloom theory 2005 classifies the purpose of providing education into three domains which are namely cognitive, affective and psychomotor. Bloom theory underlies the assessment of the ability of clients in this study. Cognitive abilities include intellectual aspects such as knowledge and thinking skills, affective abilities emphasize aspects of feelings and emotions. The next ability is behavior that emphasizes motoric aspects as seen from the client's ability to carry out Cognitive Behavioral Therapy such as writing it in a workbook and a schedule of daily activities. ${ }^{18}$

In addition to these three aspects, physiological responses serve as benchmarks for observing violent behavior. In 2011, violent behavior can be seen from tense faces, being unable to stand still, clenching or hitting hands, jaw tightening, increased breathing, and sometimes suddenness such as kataton. The greatest decrease in physical symptoms occurred in a study conducted by Fauziah (2009) of 13 schizophrenia clients compared to symptoms of clients with other violent behavior, because all clients received psychopharmaceutical therapy in the form of improving cognitive abilities and antipsychotic drugs that worked effectively, each behavior reached $66 \%$ to decrease the client's physical symptoms. ${ }^{19}$ Through Cognitive Behavioral Therapy (CBT) clients are trained to be able to evaluate themselves by identifying events that have been experienced, irrational thoughts that interfere and influence the client's feelings so they behave badly that is actually not desirable. $^{20}$

Clients who received Assertive Training (AT) therapy experienced a significant increase with $\mathrm{p}$ value $<0.05$ according to table 5 . The results of this study were similar with the statement of Khamida's research which states that assertive training given to patients is useful for practicing adjustments social in expressing attitudes, feelings, opinions and rights. ${ }^{13}$

The reduction in violent behavior in schizophrenic patients after being given Assertive Training (AT) in this study is inseparable from the modeling and role play techniques conducted by 
the researcher during the intervention. The modeling and role play techniques carried out in the Assertive Training (AT) intervention are the same as those of the previous researchers. Where researchers explain first, give examples and give respondents the opportunity to practice assertive behavior that is taught in daily life.

The findings of Wahyuningsih study conveyed that there was an effect of assertive group activity therapy on behavior change in violent behavior patients, the results obtained value of $p$ value $=0,000 .^{21}$ The results of the study were similar with the results of research conducted by researchers. In assertive training, researchers teach patients to cognitively identify events, thoughts and feelings that arise as well as the effects or consequences of those thoughts and feelings in session one and identify values based on their experiences in session two. In session three psychomotor patients are trained to accept events using selected values. In the last session (session four) patients are invited to have a commitment to prevent bad behavior from recurring.

Assertive Training (AT) aim to help change perceptions to improve individual assertive abilities, express emotions and think adequately and to build self confidence. ${ }^{22}$

Based on table 7, from the results of this study it was found that Cognitive Behavioral Therapy (CBT) is more influential than Assertive training in controlling the violent behavior of schizophrenic patients. Cognitive Behavioral Therapy (CBT) can significantly reduce anger, guilt and low self-esteem. The focus of Cognitive Behavior Therapy is to provide the ability to think is education and build client skills. The therapeutic relationship between client and nurse is very important to increase the effectiveness of the nursing actions taken. Through these CBT activities, clients write down automatic negative thoughts that arise. ${ }^{1}$ The client also writes exercises to change negative thoughts and behaviors into positive thoughts and behaviors. Self-training by the client and written in a work book will improve the ability to control violent behavior. By changing the status of thoughts and feelings, the client is expected to change negative behavior into positive. Work books are used as a tool to train clients in the ability to change a client's negative thoughts into a culture or habit. ${ }^{23}$

In improving the ability to change negative behavior, researchers apply the principles of behavioral theory by providing positive reinforcement of positive behavior by clients and providing negative feedback on unwanted behavior. Videbeck (2008) states behavior modification is a method that can be used to reinforce the desired behavior or response through giving positive and negative feedback. ${ }^{24}$

Cognitive Behavioral Therapy in group is very effective in overcoming angry expression disorders, because in this therapy group members learn strategies and techniques to help regulate anger, express anger in an alternative way, change hostility, and prevent aggression behavior such as high verbal intonation and hardness. ${ }^{25}$ This process is what makes the difference with Assertive Training (AT) where negative thoughts are automatically not too much of a concern because 
someone has the fairness to be able to overcome and expel those negative thoughts independently. In addition, one's anger and resentment arises primarily because of verbal communication misconceptions.

Therefore, one of the other methods to reduce violent behavior is Assertive Training (AT) This therapy process begins with the stages of describing (describing new behaviors to be learned), learning (learning new behaviors through instructions and demonstrations), practicing or role play (practicing new behaviors by providing feedback and transferring (applying new behaviors in real situations will motivate clients to play an active role in thinking and practicing the behavioral abilities taught. ${ }^{26}$

In the first session of assertive therapy, what is done is to discuss with patients about violent behavior, types of violent behavior that have been done, the consequences and ways to control violent behavior, and motivate patients to express their opinions and thoughts about various kinds of information that are known, provide positive feedback to patients about how to control violent behavior that has been properly done so far and provide input and explanation regarding the treatment of patients with violent behavior that is unknown or not yet understood. The results of the evaluation of the implementation of the first session found that all patients were found to have carried out the first session well, although there were 2 people (20\%) patients initially passive and less open, but after being motivated and seeing other friends, they became more active and open.

The second session of Assertive Therapy (AT) is to practice assertive behavior. Assertive Training (AT) is an act to practice basic interpersonal skills that often interfere with schizophrenic clients, the ability in question is to communicate directly to others, say no to irrational requests, express disagreement and express opinions. Based on the final evaluation of the implementation of this second session all members can demonstrate how to behave assertively, for example asking and rejecting using good or assertive language.

The third session was conducted by training patients to use a group support system (support system) in controlling violent behavior. This session each patient has a list of abilities in using support between group members, being able to do demonstrations or role play how to use support, for example to remind each other if there is one of his friends willing or angry with their respective assignments which have been agreed by the group.

The fourth session was conducted to evaluate the experiences learned related to the use of support systems both from the patient's self and from outside. This session the patient told that every time he wanted to get angry immediately carry out the actions recommended in the first and second sessions. Research conducted by Mousa explained that Assertive Training (AT) had a positive effect on the ability to communicate assertively by involving nonverbal aspects. The method of implementing Assertive Training (AT) will motivate the client to play an active role in thinking and practicing the social or verbal abilities taught. ${ }^{27}$ 
Although both of these therapies are both aimed at controlling violent behavior, each of these therapies has specific characteristics or advantages that are effective in reducing the response of violent behavior.Mental health can be improved with effective public health interventions. Therefore,optimal strategies such as nursing interventions namely CBT and AT need to be undertaken for each individual,family and community by using promotive, preventive,curative and rehabilitation as a whole, integrated and sustainable. ${ }^{28}$

\section{Conclusions}

There are significant differences in violent behavior between Cognitive Behavioral Therapy (CBT) and Assertive Training (AT) treatment groups of the control group. The treatment group that was given Cognitive Behavioral Therapy, and Assertive Training had the ability to reduce violent behavior more than the control group. Cognitive Behavioral Therapy groups have the ability to reduce violent behavior more than groups given Assertive Training

\section{Acknowledgement}

This study was supported by a research and community service Grant from Sriwijaya University.We also thank the Training Division of Ernaldi Bahar Hospital for facilities and moral support that has been given to us

\section{Funding}

There is no financial support from anywhere

\section{Conflict of Interest}

There is no conflict of interest

\section{References}

1. GW S.Prinsip dan praktek keperawatan kesehatan jiwa.2nd ed.jakarta: Elsevier; 2016. 682 p

2. Keliat B. Model praktek keperawatan profesional jiwa. 2nd ed. Jakarta: EGC; 2010. 305 p.

3. Levav I, Rutz W. The WHO World Health Report 2001: Mental Health: New understanding, New hope. Vol. 39, Israel Journal of Psychiatry and Related Sciences. 2002.

4. McLean CP, Foa EB. Prolonged exposure therapy for post-traumatic stress disorder: A review of evidence and dissemination. Expert Rev Neurother. 2011;11(8):1151-63.

5. James BO, Isa EW, Oud N. Patient aggression in psychiatric services: The experience of a sample of nurses at two psychiatric facilities in Nigeria. African J Psychiatry (South Africa). 2011;14(2):130-3.

6. Hidayat E. Pengaruh Cognitive behaviour therapy(CBT) Dan Rational Emotive Behaviour 
Therapy (REBT) Terhadap Klien Perilaku Kekerasan dan Harga Diri Rendah di Rumah Sakit Dr.H.Marzoeki Mahdi Bogor. FIK UI. Uiniversitas Indonesia; 2011.

7. Astuti retno yuli, Setianingsih. Pengaruh Cognitive Behaviour Therapy pada klien dengan masalah keperawatan perilaku kekerasan dan halusinasi Di RSJD DR.RM Soedjarwadi Klaten. Keperawatan Jiwa Pengaruh Cogn Behav Ther Pada Klien dengan Masal Keperawatan Perilaku Kekerasan dan Halusinasi di RSJD DR RM Soedjarwadi Klaten. 2016;4(1):7-12.

8. Hundozi Z, Ibishi NF, Musliu NR. Cognitive functions and recidivism of aggressive behavior in schizophrenic inpatients at Forensic Unit Clinic of Psychiatry in Kosovo. Cogent Psychol [Internet]. 2016;3(1):1-16. Available from: http://dx.doi.org/10.1080/23311908.2016.1233650

9. Rustafariningsih. Pengaruh Assertive Acceptance Commitment Therapy (AACT) Terhadap Kemampuan Mengendalikan Perilaku Kekerasan Pasien Skizofrenia. Fakultas Keperawatan Universitas Airlangga Surabaya. Airlangga; 2018.

10. Hastuti RY, Keliat BA, Mustikasari. Efektivitas Rational Emotion Behaviour Therapy Berdasarkan Profile Multimodal Therapy Pada Klien Skizofrenia Dengan Masalah Keperawatan Perilaku Kekerasan Dan Halusinasi Di Rumah Sakit Jiwa. Keperawatan Indones. 2015;18(3):143-50.

11. Notoatmodjo S. Promosi kesehatan dan perilaku. 1st ed. jakarta: Rineka Cipta; 2012. 167 p.

12. Arifin Z. Metode Pendidikan dan Paradigma Baru. ke 3. Bandung: Rosdakarya; 2014. 328 p.

13. Khamida K. Terapi Kelompok Suportif Asertif Menurunkan Nilai Perilaku Kekerasan Pasien Skizofrenia Berdasarkan Model Keperawatan Interaksi King. J Heal Sci. 2015;6(2):1-10.

14. Uecker JE. Marriage and mental health among young adults. J Heal Soc Behav. 2012;53(1):67-83.

15. Stuart G wiscarz. Principles and practice of psychiatric nursing. 10th ed. St Louis Missouri: Elsevier Health Sciences; 2014. 832 p.

16. Narullita D. Faktor-Faktor Yang Mempengaruhi Harga Diri Rendah Pada Lansia Di Kabupaten Bungo Propinsi Jambi Tahun 2016. J Endur. 2017;2(3):354.

17. Wardani LK, Sari DK. Analisa Kemampuan Mengontrol Marah ditinjau dari Penerapan REBT (Rational Emotive Behaviour Theraphy) pada Klien Skizofrenia di UPT Bina Laras Kras Kediri. Str J Ilm Kesehat. 2018;7(2):57-61.

18. Fenn K, Byrne M. The key principles of cognitive behavioural therapy. InnovAiT Educ Inspir Gen Pract. 2013;6(9):579-85.

19. Fauziah. Pengaruh Terapi Perilaku Kognitif (TPK) pada klien skizofrenia dengan perilaku 
kekerasan di Rumah Sakit Marzoeki Mahdi Bogor. Universitas Indonesia; 2009.

20. Fitri D. Efektivitas Cognitive Behavior Therapy Untuk Menurunkan Kecemasan Berbicara di Depan Umum Pada Mahasiswa. J Psikol. 2017;10(1):64-73.

21. Wahyuningsih D, Keliat BA, Hastono SP. Penurunan Perilaku Kekerasan Pada Klien Skizoprenia Dengan Assertiveness Training. J Keperawatan Indones. 2011;14(1):51-6.

22. Eslami AA, Rabiei L, Afzali SM, Hamidizadeh S, Masoudi R. The effectiveness of assertiveness training on the levels of stress, anxiety, and depression of high school students. Iran Red Crescent Med J. 2016;18(1):1-10.

23. Sudiatmika IK, Keliat BA, Wardani Y. Efektivitas Cognitive Behaviour Therapy Dan Rational Emotive Behaviour Therapy Terhadap Gejala dan Kemampuan Mengontrol Emosi Pada Klien Perilaku Kekerasan. J Keperawatan Jiwa. 2013;1:1-10.

24. Mahanani FK. Operant conditioning: Shaping dan positif Reinforcement contingencies "Dari Perilaku Off Task menjadi On Task. Intuisi J Psikol Ilm. 2017;9(3):276-89.

25. Made N, Sulistiowati D, Keliat BA, Wardani IY. Pengaruh acceptance and commitment therapy terhadap gejala dan kemampuan klien dengan resiko perilaku kekerasan. J Keperawatan Jiwa. 2014;2(1):51-7.

26. Yunalia EM, Etika AN. Efektivitas Terapi Kelompok Assertiveness Training terhadap kemampuan komunikasi asertif pada remaja dengan perilaku agresif. Keperawatan Jiwa. 2019;7(3):229-36.

27. Mousa AA, Imam SA, Sharaf AY. The Effect of an Assertiveness Training Program on Assertiveness Skills and Social interaction anxiety of individuals with schizophrenia. J Am Sci. 2011;7(12):454-66.

28. Ayuningtyas D, Misnaniarti M, Rayhani M. Analisis Situasi Kesehatan Mental Pada Masyarakat Di Indonesia Dan Strategi Penanggulangannya. J Ilmu Kesehat Masy. 2018;9(1):1-10. 